\title{
PENGARUH MODEL PEMBELAJARAN BERBASIS MASALAH TERHADAP KEMAMPUAN BERPIKIR KRITIS SISWA
}

\author{
Fedi, S. ${ }^{1}$, Gunsi, A.S. ${ }^{2}$, Ramda, A.H. ${ }^{3}$, \& Gunur, B. ${ }^{4}$ \\ STKIP Santu Paulus Ruten
}

\section{INFO ARTICLES}

\section{Article History:}

Received: 24-10-2018

Revised: 6-12-2018

Approved: $18-12-2018$

Publish Online: $30-12-2018$

\section{Key Words:}

problem-based learning, critical thinking ability.

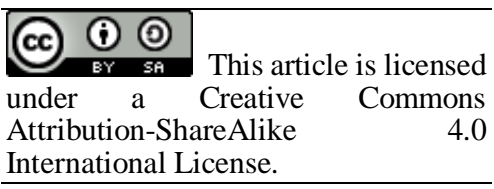

\begin{abstract}
This research is aim to compare the students critical thinking skills who engaged in a problem-based learning model with students who engaged in conventional learning. This is an experiment research, with posttest only control group design. The population is 50 of Accounting XI students in Widya Bhakti Vocational School in Ruteng, Flores. Samples grouping on nonprobability sampling, that is saturated sampling where all of this population members are used as samples. The sample in the experimental class was all 24 students of class XI Accounting 1 who received treatment problem-based learning, while the control class sample was all 26 students of class XI Accounting 2 who received conventional learning. Data is collected through tests in the form of description questions. A prerequisite test was carried out before testing the research hypothesis: the normality test and homogeneity test. The results of these prerequisite test are data in two groups indicated as normally distributed and both are homogeneous. The meaning of the results of this analysis are: (1) when compared to conventional learning models, the problem-based learning model has a more positive and significant influence on the formation of students' critical thinking skills; (2) The value of tcount $=4.005$ indicates that the average value of critical thinking skills of students using problem-based learning models is so higher than the average value of conventional learning students' critical thinking abilities
\end{abstract}

Abstrak: Tujuan penelitian ini adalah membandingkan kemampuan berpikir kritis siswa yang mengikuti model pembelajaran berbasis masalah dengan siswa yang mengikuti pembelajaran konvensional. Penelitian ini bermetode eksperimen dengan desain posttest only control group design. Populasinya meliputi 50 siswa kelas XI Akuntansi SMK Widya Bhakti Ruteng. Penentuan sampel kelas dengan cara nonprobability sampling yakni sampling jenuh di mana semua anggota populasi digunakan sebagai sampel. Sampel pada kelas eksperimen adalah seluruh 24 siswa kelas XI Akuntansi 1 yang mendapat perlakuan pembelajaran berbasis masalah, sedangkan sampel kelas kontrol adalah seluruh 26 siswa kelas XI Akuntansi 2 yang mendapat pembelajaran bermodel konvensional. Pendataan melalui tes berbentuk soal uraian. Sebelum uji hipotesis penelitian, dilakukan uji prasyarat yaitu uji normalitas dan uji homogenitas. Hasil uji prasyarat ini adalah data pada kelompok ekeperimendan kontrol, semuanya berdistribusi normal dan keduanya homogen. Maka hipotesis penelitian diuji menggunakan uji $t$. Makna hasil analisis ini adalah: (1) jika dibandingkan dengan model pembelajaran konvensional, maka model pembelajaran berbasis masalah memiliki pengaruh yang lebih positif dan signifikan terhadap pembentukan kemampuan berpikir kritis siswa; (2) Nilai $t_{\text {hitung }}=4,005$ mengindikasikan bahwa rata-rata nilai kemampuan berpikir kritis siswa yang menggunakan model pembelajaran berbasis masalah jauh lebih tinggi daripada rata-rata nilai kemampuan berpikir kritis siswa berpembelajaran konvensional

Correspondence Address: Jalan Ahmad Yani 10 Manggarai NTT Tenda, Watu, Ruteng, Kabupaten Manggarai, Nusa Tenggara Tim, 86511; e-mail: http://tyanfedi.blogspot.com/

How to Cite (APA 6th Style): Fedi, S., Gunsi, A.S., Ramda, A.H., \& Gunur, B.. (2018). Pengaruh Model Pembelajaran Berbasis Masalah Terhadap Kemampuan Berpikir Kritis Siswa Kelas Xi Akuntansi Smk Widya Bhakti Ruteng. JKPM (Jurnal Kajian Pendidikan Matematika), Vol. 4 (1), 11-20.

Copyright: Fedi, dkk. (2018)

Competing Interests Disclosures: The authors declare that they have no significant competing financial, professional or personal interests that might have influenced the performance or presentation of the work described in this manuscript. 


\section{PENDAHULUAN}

Tujuan utama pendidikan dan pembelajaran di sekolah adalah membangun kemampuan dan keterampilan peserta didik. Pendidikan dan pembelajaran berkesan asal-asalan dan mubasir, jika siswa tidak memiliki kemampuan dan keterampilan apa pun, padahal telah dididik dan mengikuti pembelajaran sekian tahun di sekolah. Sementara itu, kemampuan dan keterampilan terbentuk oleh beberapa aspek internal siswa. Keterampilan itu sendiri terbentuk dari berbagai kemampuan. Maka membangun kemampuan dilakukan lebih dahulu, kemudian membangun keterampilan.

Pada bidang matematika kita mengenal keterampilan berpikir yang erat kaitannya dengan daya matematika (mathematical power). Menurut Hamzah dan Muhlisrarini (2014: 3940). Daya matematika adalah kemampuan atau kekuatan yang berkaitan dengan karakteristik matematika. Dengan kata lain, daya matematika dapat diartikan sebagai kemampuan berpikir matematik atau melaksanakan kegiatan dan proses atau tugas matematik. Ditinjau dari kedalaman atau kerumitan kegiatan matematiknya, daya matematik digolongkan dalam dua jenis yaitu berpikir tingkat rendah (lower order thinking) dan berpikir tingkat tinggi (higher order thinking).

Berpikir tingkat tinggi adalah kemampuan bernalar yang membuat seseorang berada pada tingkat yang lebih tinggi dari informasi yang ada. Seseorang yang memiliki kemampuan berpikir tingkat tinggi, tidak sekedar memercayai data/informasi yang disajikan kepadanya, tetapi ia mampu menganalisis secara tajam tentang informasi/data tersebut, dan kemudian menentukan sikap atas informasi/data tersebut. Ciriciri orang yang memiliki kemampuan berpikir tingkat tinggi adalah (1) tidak mudah percaya suatu informasi, (2) suka menyelidiki suatu urusan, bersifat knowing everything particular object (KEPO), (3) mempunyai sense of metacognitive (kepekaan metakognitif), (4) mampu mengevaluasi/mengkritisi suatu informasi, (5) mampu menemukan berbagai cara dalam menyelesaikan masalah, (6) berani berdebat dan mengungkapkan pikiran, (7) fleksible/mampu beradaptasi dan bersifat terbuka/open mind/jujur, (8) mampu menyelesaikan suatu persoalan/masalah secara mandiri/sendirian.

Namun kenyataan di lapangan, tingkat kemampuan berpikir kritis siswa masih tergolong rendah. Hal ini terungkap dari survey yang dilakukan oleh mahasiswa PPL pada salah satu sekolah kejuruan di Ruteng Flores, tahun 2017. Ditemukan bahwa siswa cenderung mengikuti penjelasan guru atau contoh di buku saja, cenderung menggunakan rumus secara mekanis. Dalam arti bahwa siswa mengikuti contoh secara kaku, hanya mengubah angka perhitungan. Siswa juga menerapkan rumus secara kaku, seolah-olah rumus adalah sebuah perangkat reparasi mesin, yang bentuk dan ukurannya tidak dapat diubah lagi. Siswa tidak mampu mengembangkan rumus ke dalam bentuk lain dan sulit menerjemahkannya ke masalah nyata kehidupan.

Ketika diberikan soal cerita (masalah nyata kehidupan), siswa sulit untuk menyelesaikan soal tersebut. Siswa tidak dapat secara kritis menerjemahkan suatu konsep dan rumusan matematika ke dalam bentuk konkrit. Siswa tidak bisa menggunakan keterampilan berpikir kritis, dengan indikasi (1) siswa cenderung menghafal prosedur/langkah kerja dari contoh soal, (2) siswa tidak mampu merumuskan masalah (baik secara bahasa umum maupun secara simbolis matematika), (3) siswa tidak dapat memfokuskan masalah, (4) siswa sulit mengidentifikasi asumsi-asumsi terkait masalah, (5) siswa sulit menentukan solusi dari permasalahan, dan (6) siswa sulit menyatakan kesimpulan/solusi akhir dari suatu permasalahan. 
Didapati bahwa siswa cenderung menghafal prosedur/langkah kerja dari contoh soal, tanpa mengkritisi langkah-langkah tersebut, tidak menggunakan pikiran sendiri, cenderung mengikuti pola/alur pikiran pada penjelasan guru atau contoh soal. Saat diberikan soal yang berlainan bentuknya, siswa akan kesulitan mengerjakan soal tersebut. Bahkan ada siswa yang mengerjakan soal tersebut persis seperti contoh soal, tanpa menyadari bahwa seharusnya langkah kerja dari soal tersebut berbeda dengan langkah kerja pada contoh soal. Hal ini menyebabkan hasil belajar matematika siswa rendah. Salah satu indikasinya adalah rendahnya hasil ujian mid semester ganjil 2017 (tentang program linear). Nilai-nilai yang diperoleh siswa cenderung kurang dari KKM, yaitu kurang dari 65. Ini bukan semata-mata kesalahan guru di kelas saat ini. Pendidikan dan pembelajaran terdahulu (pada tingkat sebelumnya) juga mememiliki andil pembentukan kemampuan berpikir kritis siswa. Tetapi sebaiknya, guru pada saat ini juga membentuk kemampuan berpikir kritis siswa. Dalam hal ini, model pembelajaran harus benar-benar menstimulus siswa untuk berpikir kritis.

Secara umum dalam dunia pendidikan, guru tidak boleh memandang pembelajaran sekedar sebagai prosedur menuntaskan materi mata pelajaran. Guru juga tidak boleh memandang pembelajaran hanya sebagai perwujudan tugasnya mentransfer ilmu, yang diimbalkan dengan gaji guru. Guru harus menyadari bahwa pembelajaran adalah proses pembangunan skill dalam diri siswa dan pembelajaran adalah latihan berpikir dan bertindak untuk menyelesaikan suatu masalah. Pembelajaran tidak sekedar mengikuti contoh prosedur kerja, tetapi pembelajaran adalah latihan mengeluarkan pikiran, sedangkan contoh hanyalah sebagai suatu bahan studi perbandingan. Guru tidak boleh sekedar menuntut siswa untuk menghafal konsepkonsep yang diberikan, dengan orientasi materi pelajaran cepat dituntaskan. Penumpukan informasi/konsep pada subjek didik dapat saja burang bermanfaat bahkan tidak bermanfaat sama sekali jika hal tersebut hanya dikomunikasikan oleh guru kepada subjek didik melalui satu arah (siswa dipasifkan, sekedar menerima dan mencatat cara penyelesaian suatu masalah). Jika guru hanya sekedar mengejar ketuntasan materi, sekedar menjalankan tugas, maka siswa tidak sedang belajar mengembangkan diri, tetapi siwa dipaksakan menampung warisan pengetahuan dan dipaksakan mengikuti bagaimana cara kerja sang guru. Sementara menurut Slavin (2011: 37), salah satu tujuan bersekolah adalah untuk meningkatkan kemampuan berpikir kritis siswa, supaya mampu membangun keputusan rasional tentang sesuatu yang harus dilakukan/diyakini.

Salah satu upaya yang dapat dilakukan untuk mengatasi masalah tersebut adalah dengan memilih model pembelajaran yang sesuai dengan level perkembangan siswa dan memancing siswa untuk berpikir kritis dan mampu mengkreasikan solusi suatu permasalahan. Untuk siswa SMK, salah satu model pembelajaran yang dapat digunakan sebagai alternative untuk mengembangkan kemampuan berpikir kritis siswa adalah pembelajaran berbasis masalah (PBM). Dalam hal ini, guru memberikan masalah yang benar-benar menantang dan membuat siswa tertarik untuk menyelesaikannya.

Menurut Mohamad Nur (dalam Novitasari, 2014: 7), pembelajaran berbasis masalah dirancang untuk membantu siswa: (1) mengembangkan keterampilan berpikir, pemecahan masalah, dan intelektual; (2) belajar peran-peran orang dewasa dengan menghayati peran-peran itu melalui situasi-situasi nyata atau yang disimulasikan; (3) menjadi mandiri atau otonom.

Pembelajaran Berbasis Masalah adalah model pengajaran yang bercirikan adanya permasalahan nyata sebagai konteks untuk para peserta didik belajar berpikir kritis dan keterampilan memecahkan masalah serta memperoleh pengetahuan. Menurut Krajcik \& Blumenfeld 
(Eggen \& Kauchak, 2012: 307), kegiatan pembelajaran berbasis masalah memfokuskan suatu masalah dan pemecahannya. Siswa yang terlibat dalam pembelajaran berbasis masalah memerlukan satu masalah untuk dipecahkan. Menurut Alzianina (2016: 4), pembelajaran berbasis masalah merupakan sebuah model pembelajaran yang menyajikan masalah dunia nyata sehingga merangsang siswa untuk belajar berpikir kritis dan membangun keterampilan pemecahan masalah, serta untuk memperolah pengetahuan dan konsep matematika.

Dari paparan terakhir di atas, dapat diklaim bahwa model pembelajaran berbasis masalah (PBM) merupakan salah satu model pembelajaran matematika yang dapat membangun dan mengembangkan kemampuan berpikir kritis siswa. Sesuai pendapat para ahli di atas, syarat PBM adalah menyajikan masalah dunia nyata sebagai suatu konteks bagi siswa untuk belajar. Dalam PBM guru berperan sebagai perancang dan pengelola pembelajaran, bukan sebagai nara sumber super yang memaksakan pikirannya menjadi pikiran orang lain. Melalui PBM, siswa belajar berpikir kritis dan membangun keterampilan dalam memecahkan masalah, bukan sekedar menjiplak pikiran guru atau menjiplak contoh pada buku. Sehingga melalui model pembelajaran berbasis masalah siswa melatih diri untuk berpikir kritis. Tim kami tertarik untuk meneliti apakah ada pengaruh yang positif dan signifikan antara PBM dengan pembentukan kemampuan berpikir kritis siswa? Penelitian ini kami laksanakan di kelas XI Akuntansi SMK Widya Bhakti Ruteng, Flores pada tahun ajaran 2017/2018. Pertanyaan besarnya adalah: apakah kemampuan berpikir kritis pada siswa kelas XI Akuntansi SMK Widya Bhakti Ruteng tahun ajaran 2017/2018 yang berpembelajaran model PBM lebih tinggi daripada siswa yang berpembelajaran model konvensional?

\section{METODE}

Jenis penelitian ini adalah kuantitatif, dengan metode eksperimen semu. Penelitian didesain dalam bentuk quasi experimental design yaitu Posttest-Only Control Group Design. Dalam hal ini, kelompok pertama disebut kelompok eksperimen dan diberi perlakuan PBM, sedangkan kelompok lainnya bertindak sebagai kontrol terhadap PBM. Kelompok control ini mendapat pembelajaran dengan metode konvensional yaitu metode yang biasa dipakai oleh guru, di mana contoh soal diberikan kemudian diikuti latihan soal oleh siswa.

Tabel 1: Posttest-Only Control Group Design

\begin{tabular}{lcc}
\hline Kelas & Perlakuan & Posttest \\
\hline Eksperimen & $\times$ & $O_{1}$ \\
Kontrol & - & $O_{2}$ \\
\hline
\end{tabular}

Keterangan:

$\times$ : Perlakuan dengan model pembelajaran berbasis masalah

$O_{1}$ : Postest pada kelas eksperimen

$\mathrm{O}_{2}$ : Postest pada kelas control

Populasi penelitian ini adalah seluruh 50 siswa jurusan Akuntansi (AK) Kelas XI SMK Widya Bhakti, Ruteng, Flores. Terbagi dalam 2 rombongan belajar. Penentuan sampel dilakukan secara nonprobability sampling yakni jenis sampling jenuh. Dalam hal ini, semua anggota populasi terlibat sebagai sampel. Sampel 
dari penelitian ini adalah kelas yang menjadi populasi penelitian yaitu XI Akuntansi I dan XI Akuntansi II SMK Widya Bhakti Ruteng, Flores yang akan dijadikan sebagai kelas kontrol dan kelas eksperimen. Pengumpulan data menggunakan teknik tes, yang dilakukan dengan cara memberikan sejumlah pertanyaan (soal) terkait materi yang telah dipelajari populasi penelitian, dalam pembelajaran yang khusus didesain sesuai masalah penelitian.

\section{HASIL}

Uji normalitas dilakukan untuk mengetahui apakah sampel yang diteliti berasal dari populasi yang bedistribusi normal atau tidak berdistribusi normal. Pengujian ini menggunakan statistik chi kuadrat dengan panduan seperti pemikiran Sugiyono (2012). Hasilnya adalah sebagai berikut.

Tabel 2: Hasil Uji Normalitas

\begin{tabular}{ccccc}
\hline No & Kelas & $\chi_{\text {hitung }}^{2}$ & $\chi_{\text {tabel }}^{2}$ & Kesimpulan \\
\hline $\mathbf{1}$ & Eksperimen & 4,36 & 11,0705 & Data berdistribusi normal \\
$\mathbf{2}$ & Kontrol & 6,73 & 11,0705 & Data berdistribusi normal \\
\hline
\end{tabular}

Uji homogenitas varians digunakan untuk mengetahui apakah kedua kelas homogen atau tidak homogen. Di bawah ini akan disajikan hasil uji homogenitas kelas eksperimen dan kelas kontrol.

Tabel 3 : Hasil Uji Homogenitas Data

\begin{tabular}{|c|c|c|c|c|c|}
\hline Kelas & $\begin{array}{l}\text { Jumlah } \\
\text { Sampel }\end{array}$ & $\begin{array}{c}\text { Varians } \\
\left(\sigma^{2}\right)\end{array}$ & $F_{\text {hitung }}$ & $F_{\text {tabel }}$ & Kesimpulan \\
\hline Eksperimen & 24 & 78,15 & 1,066 & 1,9643 & Data \\
\hline Kontrol & 26 & 73,31 & & & homogeny \\
\hline
\end{tabular}

Hipotesis yang digunakan untuk masalah kemampuan berpikir kritis pada siswa kelas XI Akuntansi SMK Widya Bhakti Ruteng tahun ajaran 2017/2018 adalah sebagai berikut:

H0: Kemampuan berpikir kritis siswa yang belajar dengan model pembelajaran berbasis masalah (PBM) tidak lebih tinggi daripada kemampuan berpikir kritis siswa yang belajar dengan model pembelajaran konvensional.

H1: Kemampuan berpikir kritis siswa yang belajar dengan model pembelajaran berbasis masalah (PBM) lebih tinggi daripada kemampuan berpikir kritis siswa yang diajarkan dengan menggunakan pembelajaran konvensional.

Hipotesis satatistikanya adalah

$$
\begin{aligned}
& \mathrm{H} 0: \mu 1<\mu 2 \\
& \mathrm{H} 1: \mu 1>\mu 2
\end{aligned}
$$

Dengan $\mu 1=$ nilai rata-rata pada kelas ekeperimen (kelas PBM), dan $\mu 2=$ nilai rata-rata kelas kontrol (kelas konvensional). Deskripsi data penelitian untuk menguji hipotesis di atas adalah sebagai berikut: 
Tabel 4: Ringkasan perhitungan skor kemampuan berpikir kritis

\begin{tabular}{lcc}
\hline \multicolumn{1}{c}{ Statistik } & $\begin{array}{c}\text { Kelas } \\
\text { Eksperimen }\end{array}$ & $\begin{array}{c}\text { Kelas } \\
\text { Kontrol }\end{array}$ \\
\hline Jumlah Siswa (N) & 24 & 26 \\
Mean & 78,89 & 66.07 \\
Nilai Maximum & 93 & 78 \\
Nilai Minimum & 62 & 51 \\
Standar Deviasi & 8,84 & 8,56 \\
Varians & 78,15 & 73,31 \\
Median & 80 & 66,67 \\
Modus & 80 & 69 \\
\hline
\end{tabular}

Berdasarkan perhitungan pada data penelitian, diperoleh rata-rata posttes kelas eksperimen adalah 78,89 dengan varians 78,15. Sedangkan rata-rata posttest kelas kontrol adalah 66.07 dengan varians 73,31 . Maka diperoleh thitung=4,005. Nilai statistik t pada taraf signifikan 95\% $(a=5 \%)=$ tabel=1,6772. Tampak bahwa thitung $=4,005>1,6772=$ ttabel maka H0 ditolak, sebaliknya H1 diterima.

\section{PEMBAHASAN}

Karena nilai H0 ditolak menunjukkan keunggulan rata-rata kemampuan berpikir kritis siswa kelas eksperimen (PBM) terhadap kelas kontrol artinya kemampuan berpikir kritis siswa yang diajarkan dengan menggunakan model pembelajaran berbasis masalah (PBM) lebih tinggi daripada kemampuan berpikir kritis siswa yang diajarkan dengan menggunakan pembelajaran konvensional. Sehingga dapat disimpulkan bahwa ada dampak positif penerapan model pembelajaran berbasis masalah (PBM) terhadap kemampuan berpikir kritis siswa.

Adanya perbedaan kemampuan berpikir kritis antara siswa kelas eksperimen dengan siswa kelas kontrol disebabkan karena di setiap tahap pembelajaran dengan model pembelajaran berbasis masalah, siswa dituntut mengembangkan proses berpikir dan menemukan sendiri makna konsep matematika yang dipelajari. Dengan PBM siswa harus proaktif dalam belajar, tidak hanya menyalin, tidak hanya mengikuti alur pikiran guru, tidak hanya mengikuti contoh-contoh tanpa tahu maknanya.

Tahapan model pembelajaran berbasis masalah yang dilakukan dalam penelitian ini adalah: penelitian, serta saran untuk penelitian lanjutan.

1. Guru (fasilitator) mengajukan beberapa masalah matematika kepada siswa (termasuk masalah nyata dalam kehidupan, yang relevan dengan konsep matematika yang sedang dipelajari);

2. Siswa diminta mengamati dan mengidentifikasi masalah yang dipaparkan;

Pada tahap ini, siswa dituntut untuk berpikir kritis untuk mengidentifikasi variable dan mengaitkan masalah dengan konsep matematika yang relevan;

3. Siswa dibolehkan bertanya kepada guru (fasilitator) terkait hal-hal yang belum dipahami berkaitan dengan masalah tersebut, atau jika ada kesalahan soal.

4. Guru (fasilitator) memotivasi siswa untuk mengumpulkan informasi dan melakukan eksperimen untuk mendapatkan data/sumber penjelasan dan pemecahan masalah. Siswa diminta membuat analisis tertulis berdasarkan informasi yang mereka temukan dalam soal dan memikirkan strategi yang tepat dalam 
memecahkan masalah tersebut. Sehingga siswa dituntut untuk menggunakan kemampuan berpikir tingkat tinggi.

5. Guru (fasilitator) membagi siswa dalam kelompok dan mengatur siswa sesuai

dengan pembagian kelompok, mengawasi dan mengarahkan siswa untuk menemukan pemecahan masalah. Jika ada kelompok yang mengalami kesulitan dalam pemahaman materi dan bertanya pada guru, guru berusaha mengarahkan dulu pada teman kelompoknya. Bila dalam kelompok tidak diperoleh jawaban yang memuaskan, barulah guru menjawab dan meluruskan pemahaman siswa.

6. Setelah diskusi berakhir, Guru (fasilitator) meminta perwakilan masing-masing kelompok mempresentasikan hasil diskusinya, sementara kelompok lain menanggapi. Yang dipresentasikan adalah model penyelesaian yang berbeda saja, sedangkan model penyelesaian yang sama, dipresentasikan salah satunya saja. Siswa yang lain menanggapi, mengkritisi dan menyimpulkan benar atau salah.

7. Guru (fasilitator) bersama siswa membuat rangkuman materi yang sudah dipelajari.

Tampak bahwa PBM menstimulus siswa untuk menguras pikiran dan menuangkan pikirannya dalam bentuk tulisan yaitu pernyataan-pernyataan matematika tentang solusi suatu masalah. Masalah yang diberikan (lewat soal uraian) menarik perhatian siswa dan memicu siswa untuk berpikir keras, sehingga timbullah kemampuan berpikir kritis dalam diri siswa. Stimulus ini membuat syaraf otak siswa bekerja. Artinya, dalam ranah pikiran, siswa tidak dimanjakan dengan 'asupan yang telah jadi' tetapi siswa disuguhi 'umpan' yang membuat mereka 'berjuang' mengolah nalarnya. Karena hal ini dilakukan berulang-ulang, maka terbentuklah 'kebiasaan kerja otak' yang kritis. Ini berarti pembelajaran telah membangun kemampuan berpikir kritis dalam diri siswa.

Berdasarkan pengamatan, didapat situasi bahwa ada siswa yang mencoba menyelesaikan soal-soal dari kehidupan nyata dengan caranya sendiri, sesuai dengan tingkat kognitifnya. Dalam kelompok mereka menukarkan/saling menunjukkan draft penyelesaian. Ada perdebatan antar warga kelompok, pada akhirnya mereka menyepakati (dan menuliskan) model matematika yang benar (menurut mereka).

Ini menunjukkan bahwa model PBM benar-benar membangkitkan gairah berpikir kritis matematis siswa. Indikasi bangkitnya kekritisan siswa adalah terjadinya saling mengoreksi hasil pemikiran antar anggota di dalam kelompok, saling menukarkan pekerjaan dan memaparkan alasan mengapa menulis penyelesaian seperti itu. Mereka dengan tegas menyepakati mana penyelesaian yang benar dan mana penyelesaian yang salah.

Saat mempresentasikan hasil kerja kelompok, mereka tampak tidak canggung. Bahkan ada yang tampil tanpa membawa kertas kerja, langsung menjelaskan penyelesaian (disertai tulisan jawaban di papan tulis). Terjadi beberapa interupsi untuk satu penyelesaian soal. Ada siswa dari kelompok lain yang menyanggah langkah-langkah penyelesaian. Kelas menjadi ajang adu pendapat. Siswa yang mempresentasikan pekerjaan juga tidak mau mengalah. Ia dengan lincah memberikan penjelasan yang lebih rinci. Ada juga yang langsung menerima koreksi pembenaran. Ini menunjukkan bahwa siswa terbuka menerima masukan dan mampu menjustifikasi pekerjaan: 'mana yang lebih benar, mana yang kurang benar'.

Di sini, siswa tidak memposisikan dirinya sebagai pendengar saja (come not to listen only). Tetapi siswa benar-benar hadir secara utuh jiwa dan raganya: berpikir dalam fisik seorang siswa. Siswa benar-benar distimulus untuk menyampaikan gagasan dan menanggapi gagasan orang lain. Ketika tes akhir penelitian 
(post test), kelas dengan model PBM ini memiliki nilai rata-rata jauh di atas kelas dengan model pembelajaran konvensional, yaitu 78,89 berbanding 66,07.

Keadaan sebaliknya terjadi di kelas dengan model pembelajaran konvensional (metode ceramah, tanya jawab dan latihan soal) pada kelas control/ kelas XI Akuntansi 2. Saat guru berceramah, terlihat siswa hanya duduk diam sambil mendengar penjelasan guru. Selama fase penjelasan ini, siswa menjadi tidak aktif. Berikut langkah-langkah pembelajaran yang dilakukan di kelas control dengan menggunakan metode ceramah.

(1) Guru menjelaskan materi di depan kelas dan seluruh siswa mendengarkan dengan baik penjelasan guru dan mengamati masalah yang dipaparkan

(2) Guru memotivasi siswa untuk menanyakan hal-hal yang belum dipahami.

(3) Setelah mendengarkan penjelasan guru, siswa menemukan dan mencari tahu di buku referensi, dan menginformasikan apa yang telah diketahui dari masalah yang dipaparkan.

(4) Siswa mengerjakan latihan soal yang diberikan untuk didiskusikan dengan teman duduknya (sebangku).

(5) Guru mempersilahkan beberapa siswa untuk memprensentasikan hasil kerjanya.

(6) Setelah siswa selesai mempresentasikan hasil kerjanya, terdapat sesi tanya jawab antara siswa yang satu dengan siswa yang lain maupun siswa dengan guru mengenai materi yang belum mereka pahami.

(7) Tahapan akhir yang dilakukan adalah siswa bersama dengan guru melakukan refleksi terhadap materi yang telah disampaikan.

Dalam pembelajaran konvensional guru menjelaskan materi dengan prinsip runtun, runtut dan runut. Artinya, guru menjelaskan materi secara berturut-turut sesuai Pokok Bahasan dan Sub Pokok Bahasan di dalam buku teks. Penjelasan ini seperti sebuah 'rentetan pengumuman' berisi materi matematika yang wajib didengar dan dicerna siswa. Sejatinya, dengan metode pembelajaran ini, guru berusaha memaksakan siswa agar ada runut isi pengumuman materi yang diterima siswa. Maksud runut di sini adalah ada jejak, seperti bekas tapak kaki, dan ada alur contoh yang direkam siswa. Runut (bekas) ini adalah isi materi matematika yang dapat direkam siswa, yang disertai dengan alur (prosedur) penyelesaian contoh soal. Siswa kemudian mengikuti cara-cara tersebut.

Jika dianalogikan, maka dalam metode konvensional, siswa seolah-olah dibimbing masuk ke hutan untuk mencari buah-buah matematika. Siswa wajib mencari pola jejak di tengah rimba raya, rimba konsep matematika. Siswa wajib mengikuti pola jejak pemandu yang telah berjalan lebih dahulu. Artinya, wajib mengikuti petunjuk sang guru yang telah menguasai rimba konsep matematika. Sekalipun ada lintasan singkat menuju tujuannya. Dalam metode konvensional, siswa diberi kesempatan untuk mencatat, selanjutnya guru memberikan soal-soal latihan untuk dikerjakan di buku latihan. Setelah selesai mengerjakan soal, beberapa siswa diminta untuk mempresentasikan hasil kerjanya di depan kelas dan disaksikan oleh teman-teman sekelasnya. Guru memberi kesempatan bertanya kepada siswa mengenai halhal yang belum dipahami.

Pembelajaran dengan pendekatan konvensional membuat siswa hanya duduk diam dan mendengar penjelasan guru sehingga keaktifan siswa tidak optimal. Ini berarti, siswa tidak dirangsang untuk berpikir secara mandiri, sebaliknya siswa dipaksakan untuk mengikuti pemikiran guru. Otak siswa diperlakukan seperti gelas: disiapkan untuk menerima tuangan. Ini mematikan kreatifitas gaya berpikir siswa, mematikan daya kritis dalam pikiran sisiwa. 
Siswa yang belum mengerti kadang tidak berani atau malu untuk bertanya pada guru. Pada waktu mengerjakan soal latihan hanya siswa yang pandai saja yang serius mengerjakan soal yang diberikan oleh guru sedangkan yang lain lebih asyik bercerita dengan temannya. Dari penjelasan-penjelasan di atas, tidak heran bahwa hasil penelitian ini menunjukkan bahwa model pembelajaran berbasi masalah (PBM) memiliki pengaruh positif dan signifikan yang jauh melampaui pengaruh pembelajaran konvensional terhadap pembangunan kemampuan berpikir kritis dalam diri siswa. Metode PBM mampu melatih siswa untuk berpikir secara ilmiah, mampu membuat siswa lebih aktif, mandiri, bertanggung jawab, berani mengemukakan ide, mampu bekerja sama dalam kelompok, berhasil memecahkan masalah yang disajikan guru, membuat suasana belajar menyenangkan, serta mampu mendorong siswa untuk mengembangkan dan meningkatkan kemampuan berpikir kritis.

Selain di SMK Widya Bhakti Ruteng, Flores, di tempat-tempat lain, di mana berdasarkan kajian hasil penelitian yang relevan terkait model pembelajaran berbasis masalah (PBM), juga menunjukkan bahwa kemampuan berpikir kritis siswa yang diajarkan dengan menggunakan model pembelajaran berbasis masalah (PBM) lebih tinggi daripada siswa yang diajarkan dengan menggunakan pembelajaran konvensional. Model ini bercirikan penggunaan masalah dunia nyata sebagai sesuatu yang harus dipelajari siswa untuk melatih dan meningkatkan keterampilan berpikir kritis dan pemecahan masalah serta mendapatkan pengetahuan konsep-konsep penting.

Model PBM dirancang untuk membantu siswa mengembangkan keterampilan berpikir, keterampilan penyelesaikan masalah dan keterampilan intelektualnya. Dengan demikian dapat disimpulkan bahwa penerapan model pembelajaran berbasis masalah dalam pembelajaran matematika memberikan pengaruh yang positif bagi kemampuan berpikir kritis siswa kelas XI Akuntansi SMK Widya Bhakti Ruteng. Berdasarkan uraian diatas, tampak bahwa model pembelajaran berbasis masalah (PBM) berpengaruh positif terhadap kemampuan berpikir kritis siswa, sehingga kemampuan berpikir kritis siswa yang menggunakan model pembelajaran berbasis masalah (PBM) lebih tinggi daripada kemampuan berpikir kritis siswa yang menggunakan pembelajaran konvensional pada siswa kelas XI SMK Widya Bhakti Ruteng tahun ajaran $2017 / 2018$.

\section{SIMPULAN}

Berdasarkan hasil penelitian dan pembahasan dapat disimpulkan bahwa kemampuan berpikir kritis siswa yang menggunakan model pembelajaran berbasis masalah (PBM) lebih tinggi dibandingkan dengan kemampuan berpikir kritis siswa yang menggunakan model pembelajaran konvensional. Jadi, direkomendasikan bahwa untuk membangun kemampuan berpikir kritis siswa, sebaiknya menggunakan model PBM. Karena kemampuan berpikir kritis adalah unsu utama kemampuan berpikir tingkat tinggi, maka diharapkan PBM diterapkan di sekolah-sekolah untuk membangun penalaran siswa. 


\section{DAFTAR RUJUKAN}

Alzianina, E. A. (2016). Pengaruh Penerapan Model Berbasis masalah Terhadap Kemampuan Komuniksi Matematis Siswa. Bandar Lampung: FKIP Unversitas Lampung.

Eggen, P. \& Kauchak, D. (2012). Strategi dan Model Pembelajaran. Jakarta: Indeks.

Novitasari. (2014). Penerapan Model Pembelajaran Berbasis Masalah Untuk Meningkatkan Prestasi Belajar Matematika Siswa Kelas V MI Wetan Sumber gempol Tulungagung. Tulungagung: FTIK Institut Tulungagung.

Slavin, R. E (2011). Psikologi Pendidikan: Teori dan Praktik. Jakarta: Permata. Puri Media.

Trianto. (2012). Mendesain Model Pembelajaran Inovatif-Progresif, Konsep, Landasan, dan Implementasinya Pada Kurikulum Tingkat Satuan Pendidikan (KTSP). Jakarta: Kencana Prenada Media Group.. 